\title{
Hemoglobin A1c, Not Glycated Albumin, Can Independently Reflect the Ankylosing Spondylitis Disease Activity Score
}

\author{
Sejin Byun, Seung Min Jung, Jason Jungsik Song, Yong-Beom Park, Sang-Won Lee \\ Division of Rheumatology, Department of Internal Medicine, Yonsei University College of Medicine, Seoul, Korea
}

\begin{abstract}
Objective. This study examined whether glycated hemoglobin (HbA1c) and glycated albumin (GA) are well correlated with the Ankylosing Spondylitis Disease Activity Score (ASDAS)-erythrocyte sedimentation rate (ESR), and ASDAS-C-reactive protein (CRP) in AS patients without medical conditions affecting the glycated protein levels. Methods: The data of 76 patients with AS were analyzed. Univariate and multivariate analyses of the variables associated with ASDAS-ESR and ASDAS-CRP were performed using a linear regression test. The patients were divided into active and inactive AS groups based on an ASDAS-CRP of 2.1 , and the variables between the two groups were compared. Results. ASDAS-ESR did not correlated with either HbA1c or GA. ASDAS-CRP was positively correlated with $\mathrm{HbA} 1 \mathrm{c}(\mathrm{r}=0.315, \mathrm{p}=0.006)$ and the white blood cell $(r=0.288, p=0.012)$, and inversely correlated with hemoglobin $(r=-0.241, p=0.036)$ and serum albumin $(r=-0.262, p=0.022)$, but not GA. Multivariate analysis revealed HbA1c and white blood cell to be significantly correlated with ASDAS-CRP ( $\beta=0.234$, $\mathrm{p}=0.033$ and $\beta=0.265, \mathrm{p}=0.017$ ). The mean $\mathrm{HbA} 1 \mathrm{c}$, not $\mathrm{GA}$, of the active group was significantly higher than that of the inactive group $(p=0.020$ ). In addition, the optimal cut-off value of $\mathrm{HbA} 1 \mathrm{c}$ was set to 5.6 , and the patients with $\mathrm{HbA} 1 \mathrm{c} \geq 5.6$ were found to have a 3.3 times higher risk of active AS than those without. Conclusion. HbA1c was significantly correlated with ASDAS-CRP, and could be a useful marker to reflect ASDAS-CRP in AS patients without medical conditions affecting the glycated protein levels. (J Rheum Dis 2018;25:131-139)
\end{abstract}

Key Words. Ankylosing spondylitis, Glycated hemoglobin A, Glycosylated serum albumin

\section{INTRODUCTION}

Ankylosing spondylitis (AS) is a chronic inflammatory disease that has characteristics of both articular and extra-articular manifestations ranging from inflammatory back pain to uveitis [1]. Before the era of biological disease modifying anti-rheumatic drugs (bDMARDs), the primary goal of therapeutic strategies for AS were to reduce pain and improve the daily activity through conventional synthetic DMARDs (csDMARDs). Despite the use of csDMARDs, however, the progression of AS could not easily delayed or modified at all [2]. Meanwhile, bDMARDs can directly quench the inflammatory response of AS, and in turn, it can minimize AS progression at earlier phase and prevent its systemic complications [3]. Thus, if we can precisely assess the disease activity of AS and not miss the proper time to start bDMARDs, we may expect a good prognosis in AS patients.

However, since the entity of AS is mainly characterized by localized inflammation, especially confined to axial joints, there have been discrepancies between conventional inflammatory markers, including erythrocyte sedimentation rate (ESR) or C-reactive protein (CRP) and the disease activity of AS in a considerable number of patients [4]. In the clinical settings, Bath Ankylosing Spondylitis Disease Activity Index (BASDAI) is the most widely used tool to assess the disease activity of AS for its convenience. But BASDAI has a limitation that it does not include physician's assessment nor objective evidence of inflammation, because it consists of only patient-reported

Received : January 24, 2018, Revised : February 27, 2018, Accepted : February 28, 2018

Corresponding to : Sang-Won Lee (iD http://orcid.org/orcid.org/0000-0002-8038-3341

Division of Rheumatology, Department of Internal Medicine, Yonsei University College of Medicine, 50-1 Yonsei-ro, Seodaemun-gu, Seoul 03722, Korea. E-mail : sangwonlee@yuhs.ac

Copyright (c) 2018 by The Korean College of Rheumatology. All rights reserved.

This is a Open Access article, which permits unrestricted non-commerical use, distribution, and reproduction in any medium, provided the original work is properly cited. 
items [5]. To complement it, a new composite index, Ankylosing Spondylitis Disease Activity Score (ASDAS), has been suggested. It adds objective laboratory findings including ESR and CRP to patient-reported items (ASDASESR and ASDAS-CRP) [6]. However, so far, there has been no single serum marker to reflect the disease activity of AS.

Glycated proteins, which are produced through non-enzymatic reaction between sugars and free amino groups of proteins, can be formed in diverse pathological or physiological conditions such as diabetes mellitus and inflammation $[7,8]$. Glycated hemoglobin (HbAlc) and glycated albumin (GA) are glycated proteins and they can identify plasma glucose concentration in different follow-up durations $[9,10]$. Moreover, $\mathrm{HbAlc}$ and GA were recently reported that they could reflect and monitor the inflammatory burdens $[11,12]$. But there has been no report regarding the association of $\mathrm{HbAlc}$ and GA with the disease activity of AS yet. Hence, in this study, we investigated whether glycated proteins, HbAlc and GA, are adjunctive markers to be well correlated with ASDAS-ESR and ASDAS-CRP in AS patients, who had normal laboratory results including $\mathrm{HbAlc}, \mathrm{GA}$ and fasting glucose, and who had no medical history of abnormal glucose metabolism and other medical conditions affecting glycated protein levels.

\section{MATERIALS AND METHODS}

\section{Patients}

We consecutively enrolled 94 patients with AS in this study from March 2015 to October 2015 according to the inclusion criteria as follows: (i) patients who fulfilled modified New York criteria for AS [13], and who had been classified at the Division of Rheumatology, Yonsei University College of Medicine, Severance Hospital; (ii) patients who had no medical history which can influence on the turnover of albumin and red blood cell, including other autoimmune diseases other than AS [12], diabetes mellitus [14], thyroid disease [15], nephrotic syndrome [16], chronic liver diseases [17], and haemolytic anaemia [18] identified by 10th revised international classification of diseases; (iii) patients who had never received medications for those diseases searched by the Korean Drug Utilization Review system; (iv) patients who had no concurrent infection and malignancy to enhance acute reactants levels; (v) patients who gave informed consent to their participation; (vi) patients who took clinical assess- ment by independent physician on the same day of laboratory tests; (vii) patients having laboratory results fulfilling the following criteria: fasting glucose $<126$ $\mathrm{mg} / \mathrm{dL}, \mathrm{HbAlc}<6.5 \%$, platelet count $>150,000 / \mathrm{mm}^{3}$, creatinine $\leq 1.3 \mathrm{mg} / \mathrm{dL}$ or estimated glomerular filtration rate by the Chronic Kidney Disease Epidemiology Collaboration $>60 \mathrm{~mL} / \mathrm{min} / 1.73 \mathrm{~m}^{2}$, serum albumin $\geq$ $3.5 \mathrm{mg} / \mathrm{dL}$, alkaline phosphatase $\leq 115 \mathrm{IU} / \mathrm{L}$, aspartate aminotransferase $\leq 40 \mathrm{IU} / \mathrm{L}$, alanine aminotransferase $\leq$ $40 \mathrm{IU} / \mathrm{L}$. We excluded 7 of 94 patients due to medical conditions and 11 of the rest due to the laboratory results exceeding normal values. Finally, we included 76 patients with AS in this study. Demographic features included age, gender, smoking history, body mass index (BMI), the follow-up duration and the use of glucocorticoid and anti-tumour necrosis factor agents. This study was approved by the Institutional Review Board of Severance Hospital (no. 4-2015-0802). Informed consent was obtained from all patients.

\section{Laboratory tests and disease activity assessment} HbA1c levels were measured via automated COBAS INTEGRA 800 (Roche Diagnostics, Mannheim, Germany). GA levels were measured using a Hitachi 7600-120 automatic analyser (Hitachi, Tokyo, Japan) and an enzymatic method and an albumin detection reagent (Lucica GA-L; Asahi Kasei Pharma Co., Tokyo, Japan). We selected items of laboratory tests, which are routinely performed at each regular visit, as described in Table 1. ASDAS-ESR and ASDAS-CRP were also obtained by the equations as below: $0.08 \times$ Back Pain $+0.07 \times$ Duration of Morning Stiffness $+0.11 \times$ Patient Global $+0.09 \times$ Peripheral Pain/ Swelling $+0.29 \times \sqrt{(E S R)}$ for ASDAS-ESR and $0.12 \times$ Back Pain $+0.06 \times$ Duration of Morning Stiffness $+0.11 \times$ Patient Global $+0.07 \times$ Peripheral Pain/Swelling $+0.58 \times$ Ln $(C R P+$ 1) $[6,19]$. Also we assessed the disease activity of AS such as BASDAI [5], Bath Ankylosing Spondylitis Functional Index (BASFI) [20], and Bath Ankylosing Spondylitis Patient Global Score (BAS-G) [21].

\section{Statistical analysis}

All statistical analyses were conducted using the IBM SPSS package for Windows version 23.0 (IBM Co., Armonk, NY, USA). Continuous variables were expressed as median (interquartile range) or mean \pm standard deviation. Correlations between variables were determined by the Pearson rank test. Univariate analysis of the association of variables with ASDAS-ESR and ASDAS-CRP was 
Table 1. Baseline characteristics of patients with ankylosing spondylitis $(n=76)$

\begin{tabular}{|c|c|}
\hline Variable & Value \\
\hline \multicolumn{2}{|l|}{ Demographic data } \\
\hline Age $(y r)$ & $39.0(18.0)$ \\
\hline Male gender & $58(76.3)$ \\
\hline Follow-up duration (yr) & $5.0(8.5)$ \\
\hline Smoking & $29(38.2)$ \\
\hline $\mathrm{BMI}\left(\mathrm{kg} / \mathrm{m}^{2}\right)$ & $24.0(5.0)$ \\
\hline HLA-B27 & $60(78.9)$ \\
\hline Syndesmophyte formation & $20(26.3)$ \\
\hline \multicolumn{2}{|l|}{ Laboratory results } \\
\hline $\operatorname{HbA1c}(\%)$ & $5.5(0.4)$ \\
\hline $\mathrm{GA}(\%)$ & $12.7(1.5)$ \\
\hline Fasting glucose (mg/dL) & $95.5(12.8)$ \\
\hline $\operatorname{ESR}(\mathrm{mm} / \mathrm{h})$ & $19.0(28.0)$ \\
\hline $\mathrm{CRP}(\mathrm{mg} / \mathrm{L})$ & $2.3(5.9)$ \\
\hline Ferritin $(\mathrm{mg} / \mathrm{dL})$ & $75.5(70.0)$ \\
\hline White blood cell $\left(/ \mathrm{mm}^{3}\right)$ & $7,325.0(2,580.0)$ \\
\hline Hemoglobin (g/dL) & $14.9(2.4)$ \\
\hline Platelet $\times 10^{3}\left(/ \mathrm{mm}^{3}\right)$ & $261.0(69.5)$ \\
\hline Albumin (mg/dL) & $4.4(0.5)$ \\
\hline Blood urea nitrogen (mg/dL) & $13.9(4.4)$ \\
\hline Creatinine (mg/dL) & $0.8(0.2)$ \\
\hline Alkaline phosphatase (IU/L) & $70.0(26.0)$ \\
\hline Aspartate aminotransferase (IU/L) & $21.0(8.0)$ \\
\hline Alanine aminotransferase (IU/L) & $18.0(17.0)$ \\
\hline Total cholesterol (mg/dL) & $188.0(40.5)$ \\
\hline High density cholesterol (mg/dL) & $53.0(17.0)$ \\
\hline Low density cholesterol (mg/dL) & $107.8(24.4)$ \\
\hline Triglyceride (mg/dL) & $96.0(76.0)$ \\
\hline \multicolumn{2}{|l|}{ Disease activity indexes } \\
\hline ASDAS-ESR & $2.2(1.5)$ \\
\hline ASDAS-CRP & $1.8(1.4)$ \\
\hline BASDAI & $3.3(2.4)$ \\
\hline BAS-G & $3.0(3.3)$ \\
\hline BASFI & $1.3(2.6)$ \\
\hline \multicolumn{2}{|l|}{ Medications } \\
\hline Glucocorticoid use & $7(9.2)$ \\
\hline Methotrexate use & $5(6.6)$ \\
\hline Sulfasalazine use & $39(51.3)$ \\
\hline Anti-TNF agents use & $27(35.5)$ \\
\hline
\end{tabular}

Values are expressed as median (interquartile range, IQR) or number (\%). BMI: body mass index, HLA: human leukocyte antigen, HbA1c: hemoglobin A1c, GA: glycated albumin, ESR: erythrocyte sedimentation rate, CRP: C-reactive protein, ASDAS: ankylosing spondylitis disease activity score, BASDAI: bath ankylosing spondylitis disease activity index, BAS-G: bath ankylosing spondylitis patient global score, BASFI: bath ankylosing spondylitis disease activity functional index, TNF: tumour necrosis factor. performed using linear regression test. Standardized correlation coefficient was assessed by a multivariate linear regression test using variables with significant differences on univariate analysis. The chi-square test and Fisher's exact test were used for significant differences of categorical data between the two groups. We used Student's t-test or Mann-Whitney U-test to compare continuous variables between the two groups. p-values less than 0.05 were considered statistically significant.

\section{RESULTS}

\section{Baseline characteristics of patients with ankylosing spondylitis}

Baseline characteristics are summarized in Table 1. The median age of patients was 39.0 years old (58 men and 18 women), and the median follow-up duration was 8.1 years. Twenty nine of patients (38.2\%) had smoking history, and the median BMI was $24.0 \mathrm{~kg} / \mathrm{m}^{2}$. Human leukocyte antigen B27 was detected in 60 patients (79.0\%). The median $\mathrm{HbAlc}$, GA and fasting glucose were $5.5 \%$, $12.7 \%$ and $95.5 \mathrm{mg} / \mathrm{dL}$, respectively. The median ESR and CRP were $19.0 \mathrm{~mm} /$ hour and $2.3 \mathrm{mg} / \mathrm{L}$. The median ASDAS-ERS and ASDAS-CRP were 2.2 and 1.8, and the median BASDAI, BAS-G and BASFI were assessed as 3.3, 3.0 and 1.3, respectively. Seven patients had ever received glucocorticoid and 27 patients had done anti-tumor necrosis factor (TNF) agents.

\section{Correlation of between glycated proteins and dis- ease activity}

We evaluated the correlation of $\mathrm{HbA1c}$ and GA with the disease activity indices of AS. HbAlc was remarkably correlated with GA, fasting glucose and BMI $(r=0.400$, $r=0.405$ and $r=0.227, p<0.005$ for all). HbAlc showed significantly positive correlation with ASDAS-CRP $(r=$ 0.315, $\mathrm{p}=0.006)$, but not ASDAS-ERS $(\mathrm{r}=0.220, \mathrm{p}=0.560)$. Also, HbA1c was meaningfully correlated with BASDAI $(r=0.226)$ and BAS-G $(r=0.401)$, but not BASFI $(r=0.124)$. On the other hands, GA exhibited no significant correlation with any disease activity index of AS (Supplementary Table 1).

\section{Univariate and multivariate analyses of ASDAS-ESR and other variables}

Univariate linear regression analysis revealed that ASDAS-ESR was positively correlated with white blood cell $(r=0.266, p=0.020)$ and inversely correlated with he- 
moglobin $(\mathrm{r}=-0.414, \mathrm{p}<0.001)$ and serum albumin $(\mathrm{r}=$ $-0.394, p<0.001)$. ASDAS-ESR showed a tendency to correlate with $\mathrm{Hb} 1 \mathrm{AC}$, but it was not statistically significant $(r=0.220, p=0.056)$. ASDAS-ESR was not correlated with GA (Table 2). We included HbA1c in multivariate analysis, because its p-value was almost near the statistical significance. However, on multivariate linear regression analysis, only white blood cell and hemoglobin were significantly correlated with ASDAS-ESR ( $\beta=0.266$, $\mathrm{p}=0.011$ and $\beta=-0.355, \mathrm{p}=0.002$ ).

\section{Univariate and multivariate analyses of ASDAS-CRP and other variables}

Univariate linear regression analysis discovered that ASDAS-CRP was positively correlated with $\mathrm{HbAlc}(\mathrm{r}=$ $0.315, \mathrm{p}=0.006)$ and white blood cell $(\mathrm{r}=0.288, \mathrm{p}=0.012)$ and inversely correlated with haemoglobin $(r=-0.241$, $\mathrm{p}=0.036)$ and serum albumin $(\mathrm{r}=-0.262, \mathrm{p}=0.022)$. ASDAS-CRP was not correlated with GA. On multivariate linear regression analysis, $\mathrm{HbAlc}$ and white blood cell were still significantly correlated with ASDAS-CRP ( $\beta=0.234, \mathrm{p}=0.033$ and $\beta=0.265, \mathrm{p}=0.017$ ) (Table 3). Also, we analyzed correlation between the use of medi-

Table 2. Univariate and multivariate analysis of ASDAS-ESR and other variables

\begin{tabular}{|c|c|c|c|c|c|c|}
\hline \multirow[b]{2}{*}{ Variable } & \multicolumn{3}{|c|}{ Univariate analysis } & \multicolumn{3}{|c|}{ Multivariate analysis } \\
\hline & $\begin{array}{c}\text { Regression } \\
\text { coefficient } \\
\text { (crude B) }\end{array}$ & $\begin{array}{c}\text { Correlation } \\
\text { coefficient } \\
(\mathrm{R}=\beta)\end{array}$ & p-value & $\begin{array}{c}\text { Standardized } \\
\beta^{*}\end{array}$ & $\begin{array}{c}95 \% \\
\text { confidential } \\
\text { interval }\end{array}$ & $\mathrm{p}$-value \\
\hline \multicolumn{7}{|l|}{ Demographic data } \\
\hline Age $(y r)$ & 0.013 & 0.172 & 0.136 & & & \\
\hline Follow-up duration (yr) & -0.002 & -0.011 & 0.923 & & & \\
\hline BMI $\left(\mathrm{kg} / \mathrm{m}^{2}\right)$ & 0.003 & 0.013 & 0.910 & & & \\
\hline \multicolumn{7}{|l|}{ Laboratory results } \\
\hline $\mathrm{HbA1c}(\%)$ & 0.661 & 0.220 & 0.056 & 0.102 & $-0.298,0.911$ & 0.316 \\
\hline GA $(\%)$ & 0.069 & 0.105 & 0.368 & & & \\
\hline Fasting glucose (mg/dL) & 0.001 & 0.011 & 0.923 & & & \\
\hline $\mathrm{ESR}(\mathrm{mm} / \mathrm{h})$ & N/A & N/A & N/A & & & \\
\hline $\mathrm{CRP}(\mathrm{mg} / \mathrm{L})$ & 0.054 & 0.448 & $<0.001$ & & & \\
\hline Ferritin $(\mathrm{mg} / \mathrm{dL})$ & -0.002 & -0.145 & 0.296 & & & \\
\hline White blood cell $\left(/ \mathrm{mm}^{3}\right)$ & 0.120 & 0.266 & 0.020 & 0.266 & $0.028,0.211$ & 0.011 \\
\hline Hemoglobin (g/dL) & -0.229 & -0.414 & $<0.001$ & -0.355 & $-0.316,-0.075$ & 0.002 \\
\hline Platelet $\times 10^{3}\left(/ \mathrm{mm}^{3}\right)$ & 0.003 & 0.206 & 0.074 & & & \\
\hline Serum albumin (mg/dL) & -1.187 & -0.394 & $<0.001$ & -0.195 & $-1.249,0.075$ & 0.081 \\
\hline Blood urea nitrogen (mg/dL) & 0.057 & 0.223 & 0.053 & & & \\
\hline Creatinine $(\mathrm{mg} / \mathrm{dL})$ & -0.620 & -0.104 & 0.373 & & & \\
\hline Alkaline phosphatase (IU/L) & 0.009 & 0.181 & 0.121 & & & \\
\hline Aspartate aminotransferase (IU/L) & 0.004 & 0.029 & 0.805 & & & \\
\hline Alanine aminotransferase (IU/L) & 0.004 & 0.040 & 0.734 & & & \\
\hline Total cholesterol (mg/dL) & 0.003 & 0.109 & 0.350 & & & \\
\hline High density cholesterol (mg/dL) & 0.005 & 0.078 & 0.569 & & & \\
\hline Low density cholesterol (mg/dL) & -0.001 & -0.040 & 0.765 & & & \\
\hline Triglyceride (mg/dL) & 0.002 & 0.121 & 0.366 & & & \\
\hline \multicolumn{7}{|l|}{ Medications } \\
\hline Glucocorticoid use & 0.350 & 0.106 & 0.364 & & & \\
\hline Methotrexate use & -0.056 & -0.015 & 0.901 & & & \\
\hline Sulfasalazine use & 0.385 & 0.201 & 0.082 & & & \\
\hline Anti-TNF agents use & -0.140 & -0.070 & 0.548 & & & \\
\hline
\end{tabular}

ASDAS: ankylosing spondylitis disease activity score, ESR: erythrocyte sedimentation rate, BMI: body mass index, HbA1c: hemoglobin A1C, GA: glycated albumin, CRP: C-reactive protein, TNF: tumour necrosis factor, N/A: not available. ${ }^{*}$ CRP was not included in multivariate analysis, because CRP is a variable closely correlated with ESR (ASDAS-ESR) in inflammation in order not to confound the interpretation of statistical results. 
Table 3. Univariate and multivariate analysis of ASDAS-CRP and other variables

\begin{tabular}{|c|c|c|c|c|c|c|}
\hline \multirow[b]{2}{*}{ Variable } & \multicolumn{3}{|c|}{ Univariate analysis } & \multicolumn{3}{|c|}{ Multivariate analysis } \\
\hline & $\begin{array}{c}\text { Regression } \\
\text { coefficient } \\
\text { (crude B) }\end{array}$ & $\begin{array}{l}\text { Correlation } \\
\text { coefficient } \\
(\mathrm{R}=\beta)\end{array}$ & p-value & $\begin{array}{c}\text { Standardized } \\
\beta^{*}\end{array}$ & $\begin{array}{c}95 \% \\
\text { confidential } \\
\text { interval }\end{array}$ & $p$-value \\
\hline \multicolumn{7}{|l|}{ Demographic data } \\
\hline Age $(y r)$ & 0.013 & 0.164 & 0.158 & & & \\
\hline Follow-up duration (yr) & 0.015 & 0.105 & 0.367 & & & \\
\hline $\mathrm{BMI}\left(\mathrm{kg} / \mathrm{m}^{2}\right)$ & 0.008 & 0.032 & 0.781 & & & \\
\hline \multicolumn{7}{|l|}{ Laboratory results } \\
\hline $\operatorname{HbA1c}(\%)$ & 0.972 & 0.315 & 0.006 & 0.234 & $0.060,1.383$ & 0.033 \\
\hline GA $(\%)$ & 0.091 & 0.135 & 0.244 & & & \\
\hline Fasting glucose (mg/dL) & 0.004 & 0.037 & 0.750 & & & \\
\hline $\mathrm{ESR}(\mathrm{mm} / \mathrm{h})$ & 0.026 & 0.477 & $<0.001$ & & & \\
\hline $\mathrm{CRP}(\mathrm{mg} / \mathrm{L})$ & N/A & N/A & N/A & & & \\
\hline Ferritin $(\mathrm{mg} / \mathrm{dL})$ & -0.003 & -0.199 & 0.150 & & & \\
\hline White blood cell $\left(/ \mathrm{mm}^{3}\right)$ & 0.133 & 0.288 & 0.012 & 0.265 & $0.022,0.222$ & 0.017 \\
\hline Hemoglobin (g/dL) & -0.137 & -0.241 & 0.036 & -0.204 & $-0.248,0.016$ & 0.084 \\
\hline Platelet $\times 10^{3}\left(/ \mathrm{mm}^{3}\right)$ & 0.002 & 0153 & 0.186 & & & \\
\hline Serum albumin $(\mathrm{mg} / \mathrm{dL})$ & -0.811 & -0.262 & 0.022 & -0.099 & $-1.030,0.419$ & 0.404 \\
\hline Blood urea nitrogen $(\mathrm{mg} / \mathrm{dL})$ & 0.027 & 0.104 & 0.373 & & & \\
\hline Creatinine $(\mathrm{mg} / \mathrm{dL})$ & -0.243 & -0.040 & 0.734 & & & \\
\hline Alkaline phosphatase (IU/L) & 0.011 & 0.212 & 0.068 & & & \\
\hline Aspartate aminotransferase (IU/L) & 0.015 & 0.098 & 0.402 & & & \\
\hline Alanine aminotransferase (IU/L) & 0.014 & 0.145 & 0.213 & & & \\
\hline Total cholesterol (mg/dL) & 0.004 & 0.119 & 0.307 & & & \\
\hline High density cholesterol (mg/dL) & -0.012 & -0.159 & 0.246 & & & \\
\hline Low density cholesterol (mg/dL) & 0.002 & 0.069 & 0.609 & & & \\
\hline Triglyceride (mg/dL) & 0.004 & 0.184 & 0.166 & & & \\
\hline \multicolumn{7}{|l|}{ Medications } \\
\hline Glucocorticoid use & 0.147 & 0.044 & 0.707 & & & \\
\hline Methotrexate use & 0.236 & 0.060 & 0.604 & & & \\
\hline Sulfasalazine use & 0.349 & 0.180 & 0.120 & & & \\
\hline Anti-TNF agents use & -0.325 & -0.161 & 0.166 & & & \\
\hline
\end{tabular}

ASDAS: ankylosing spondylitis disease activity score, CRP: C-reactive protein, BMI: body mass index, HbA1c: hemoglobin A1c, GA: glycated albumin, ESR: erythrocyte sedimentation rate, TNF: tumour necrosis factor, N/A: not available. *ESR was not included in multivariate analysis, because ESR is a variable closely correlated with CRP (ASDAS-CRP) in inflammation in order not to confound the interpretation of statistical results.

cations and ASDAS indexes, there was no statistical significance (Tables 2 and 3).

\section{Comparison of variables between patients with ac- tive and inactive AS based on ASDAS-CRP > 2.1}

When patients with AS had ASDAS-CRP $>2.1$, they can be considered to have high or very high disease activity. Since HbA1c showed a significant correlation with ASDASCRP, but not ASDAS-ESR, we divided patients into active (40 patients) and inactive (36 patients) groups, based on ASDAS-CRP $>2$.1. There were no significant differences in demographic data between the two groups. The mean
HbAlc of patients in active group was significantly higher than that of patients in inactive group (5.6 vs. $5.4, \mathrm{p}=0.020$ ), but the mean GA did not differ between the two groups (Table 4). Patients in active group showed the higher mean ESR and white blood cell, whereas, than the lower mean hemoglobin and serum albumin than those in inactive group (30.6 vs. 14.3, $\mathrm{p}<0.001,8,273.6$ vs. 7,088.5, $\mathrm{p}=0.013,14.0$ vs. $15.0, \mathrm{p}=0.008$ and 4.3 vs. $4.5, \mathrm{p}=0.016$, respectively). The mean ASDAS-ESR, BASDAI and BAS-G in active group were significantly higher than those in inactive group. On the other hand, the frequency of glucocorticoid, methotrexate, sulfasalazine and anti-TNF anti- 
Sejin Byun et al.

Table 4. Comparison variables between patients with active and inactive ankylosing spondylitis based on ASDAS-CRP > 2.1

\begin{tabular}{|c|c|c|c|}
\hline Variable & Inactive AS ( $\mathrm{n}=40)$ & Active AS $(n=36)$ & $p$-value \\
\hline \multicolumn{4}{|l|}{ Demographic data } \\
\hline Age $(y r)$ & $37.3 \pm 11.2$ & $40.8 \pm 12.8$ & 0.201 \\
\hline Male gender & $34(85.0)$ & $24(66.7)$ & 0.061 \\
\hline Follow-up duration (yr) & $7.7 \pm 6.4$ & $8.0 \pm 7.4$ & 0.824 \\
\hline Smoking & $14(35.0)$ & $15(41.7)$ & 0.055 \\
\hline $\mathrm{BMI}\left(\mathrm{kg} / \mathrm{m}^{2}\right)$ & $24.5 \pm 4.0$ & $23.9 \pm 4.0$ & 0.526 \\
\hline HLA-B27 & $30(75.0)$ & $30(83.3)$ & 0.374 \\
\hline \multicolumn{4}{|l|}{ Laboratory results } \\
\hline $\operatorname{HbA} 1 \mathrm{c}(\%)$ & $5.4 \pm 0.3$ & $5.6 \pm 0.3$ & 0.020 \\
\hline $\mathrm{GA}(\%)$ & $12.7 \pm 1.2$ & $13.0 \pm 1.7$ & 0.395 \\
\hline Fasting glucose (mg/dL) & $97.7 \pm 9.8$ & $95.9 \pm 9.7$ & 0.414 \\
\hline $\mathrm{ESR}(\mathrm{mm} / \mathrm{h})$ & $14.3 \pm 11.7$ & $30.6 \pm 18.8$ & $<0.001$ \\
\hline $\mathrm{CRP}(\mathrm{mg} / \mathrm{L})$ & $\mathrm{N} / \mathrm{A}$ & N/A & N/A \\
\hline Ferritin $(\mathrm{mg} / \mathrm{dL})$ & $107.7 \pm 69.4$ & $75.3 \pm 73.1$ & 0.100 \\
\hline White blood cell $\left(/ \mathrm{mm}^{3}\right)$ & $7,088.5 \pm 1,767.6$ & $8,273.6 \pm 2,280.8$ & 0.013 \\
\hline Hemoglobin $(\mathrm{g} / \mathrm{dL})$ & $15.0 \pm 1.4$ & $14.0 \pm 1.9$ & 0.008 \\
\hline Platelet $\times 10^{3}\left(/ \mathrm{mm}^{3}\right)$ & $252.1 \pm 45.4$ & $275.6 \pm 75.3$ & 0.110 \\
\hline Albumin (mg/dL) & $4.5 \pm 0.3$ & $4.3 \pm 0.3$ & 0.016 \\
\hline Blood urea nitrogen $(\mathrm{mg} / \mathrm{dL})$ & $14.1 \pm 3.4$ & $14.9 \pm 4.1$ & 0.330 \\
\hline Creatinine $(\mathrm{mg} / \mathrm{dL})$ & $0.8 \pm 0.2$ & $0.8 \pm 0.2$ & 0.551 \\
\hline Alkaline phosphatase (IU/L) & $69.1 \pm 18.1$ & $74.5 \pm 20.3$ & 0.230 \\
\hline Aspartate aminotransferase (IU/L) & $20.5 \pm 7.1$ & $21.6 \pm 5.7$ & 0.442 \\
\hline Alanine aminotransferase (IU/L) & $19.7 \pm 10.1$ & $21.7 \pm 9.5$ & 0.398 \\
\hline Total cholesterol (mg/dL) & $189.7 \pm 28.3$ & $194.0 \pm 31.6$ & 0.534 \\
\hline High density cholesterol (mg/dL) & $53.4 \pm 8.6$ & $50.7 \pm 15.8$ & 0.425 \\
\hline Low density cholesterol (mg/dL) & $116.8 \pm 31.4$ & $116.3 \pm 29.3$ & 0.945 \\
\hline Triglyceride (mg/dL) & $95.5 \pm 39.3$ & $113.4 \pm 49.1$ & 0.129 \\
\hline \multicolumn{4}{|l|}{ Disease activity } \\
\hline ASDAS-ESR & $1.8 \pm 0.6$ & $3.1 \pm 0.8$ & $<0.001$ \\
\hline ASDAS-CRP & N/A & N/A & N/A \\
\hline BASDAI & $2.5 \pm 1.2$ & $4.5 \pm 1.7$ & $<0.001$ \\
\hline BAS-G & $2.5 \pm 1.7$ & $4.7 \pm 2.2$ & $<0.001$ \\
\hline BASFI & $1.7 \pm 4.3$ & $2.9 \pm 1.8$ & 0.185 \\
\hline \multicolumn{4}{|l|}{ Medications } \\
\hline Glucocorticoid use & $2(5.0)$ & $5(13.8)$ & 0.181 \\
\hline Methotrexate use & $2(5.0)$ & $3(8.3)$ & 0.651 \\
\hline Sulfasalazine use & $19(47.5)$ & $20(55.5)$ & 0.258 \\
\hline Anti-TNF antibody use & $16(40.0)$ & $11(30.6)$ & 0.390 \\
\hline
\end{tabular}

Values are expressed as mean \pm standard deviation or number (\%). ASDAS: ankylosing spondylitis disease activity score, CRP: C-reactive protein, AS: ankylosing spondylitis, BMI: body mass index, HLA: human leukocyte antigen, HbA1c: hemoglobin A1c, GA: glycated albumin, ESR: erythrocyte sedimentation rate, BASDAI: bath ankylosing spondylitis disease activity index, BAS-G: bath ankylosing spondylitis patient global score, BASFI: bath ankylosing spondylitis disease activity functional index, TNF: tumour necrosis factor, N/A: not available.

body uses did not show statistically significant difference between the two groups.

On multivariate logistic regression analysis of these significant variables, only white blood cell and hemoglobin were independently associated with high disease activity of AS based on ASDAS-CRP of 2.1 (odds ratio [OR] $=1.442$, $95 \%$ confidential interval $[\mathrm{CI}]=1.067,1.947, \mathrm{p}=0.017$, and $\mathrm{OR}=0.656,95 \% \mathrm{CI}=0.456,0.940, \mathrm{p}=0.022$ ). The statistical significance of HbA1c disappeared on multivariate analysis $(\mathrm{OR}=4.132,95 \% \mathrm{CI}=0.704,24.240$, $\mathrm{p}=0.116$ ) (Table 5). 
Table 5. Multivariate logistic regression analysis using variables with statistical significance between patients with active and inactive ankylosing spondylitis based on ASDAS-CRP $>2.1$

\begin{tabular}{lccc}
\hline \multicolumn{1}{c}{ Variable } & Odds ratio & $95 \%$ confidence interval & p-value \\
\hline HbA1c $(\%)$ & 4.132 & $0.704,24.240$ & 0.116 \\
White blood cell $\left(/ \mathrm{mm}^{3}\right)$ & 1.442 & $1.067,1.947$ & 0.017 \\
Hemoglobin $(\mathrm{g} / \mathrm{dL})$ & 0.656 & $0.456,0.940$ & 0.022 \\
Albumin $(\mathrm{mg} / \mathrm{dL})$ & 0.482 & $0.075,3.086$ & 0.441 \\
\hline
\end{tabular}

ASDAS: ankylosing spondylitis disease activity score, CRP: C-reactive protein, HbA1c: hemoglobin A1c.

\section{DISCUSSION}

Glycated albumin is a clinical marker to predict for coronary artery disease in type 2 diabetes patients, and it is well known as having correlation with high sensitivity-CRP, TNF-alpha, and interleukin-6 level [22]. In the study using bovine serum albumin, it shows that increased advanced glycation end-products which are representative for glycated albumin in diabetic patients upregulate thrombotic responses and deteriorate vessel geometry through constant disturbed shear stress in endothelial cell [23]. Meanwhile, HbA1c is marker to reflect severity of coronary artherosclerosis in non-diabetic individuals, so it has association in lower albumin concentrations, increased concentration of CRP, fibrinogen and white blood cell level, and so on. It is because HbAlc reflects subclinical derangement in glucose metabolism caused by chronic inflammation though it has normal range [24].

In this study, we first investigated whether glycated proteins, HbA1c and GA, are adjunctive markers to be well correlated with ASDAS-ESR and ASDAS-CRP. And we demonstrated that $\mathrm{HbA1c}$ was significantly correlated with ASDAS-CRP, and HbA1c could be a useful marker to reflect ASDAS-CRP in AS patients without medical conditions affecting glycated protein levels. Meanwhile, $\mathrm{HbA1c}$ had a tendency to correlate with ASDAS-ESR, but it had no statistical significance $(p=0.056)$. In addition, we found that HbAlc was correlated with BASDAI and BAS-G with statistical significance as well, but in the present study, we focused on the ASDAS-ESR and ASDASCRP containing objective laboratory results in their equations. In the real clinical settings, a majority of physicians are measuring the levels of acute reactants, such as ESR and CRP, at each visit of patients of AS. However, most of them have no over-credulity to directly apply them to AS patients to reflect the disease activity, due to its low sensitivity and singularity in AS [25]. By contrast,
BASDAI, BAS-G and BASFI are not objectively reliable due to their limited subjective items [5]. ASDAS-ESR and ASDAS-CRP are likely to overcome these limitations by adding objective laboratory results to patient-reported forms. In this regard, our study might be valuable in terms of discovering a convenient serum marker to reflect ASDAS-CRP in AS patients, who had normal laboratory results including $\mathrm{HbA1c}$, GA and fasting glucose, and who had no medical history of abnormal glucose metabolism and other medical conditions affecting glycated protein levels.

In our previous study, we consecutively enrolled 205 patients with rheumatoid arthritis (RA) and analysed their data. And we concluded that GA increased along with the disease activity in rheumatoid factor positive RA patients, and furthermore, GA was an independent and potential predictor of active RA, comparable with ESR and CRP [12]. However, in this study, we failed to elucidate that GA was correlated with the disease activity indices of AS. GA is a newly suggested parameter for the status of glucose metabolism, and it has an advantage in that it can reflect the relatively short-term alternations in plasma glucose concentration, compared to HbAlc, whereas, HbAlc can reflect the status of glucose metabolism over 60 days ago $[9,10,26]$. In addition, the disease progression and the fluctuation of inflammatory burdens of RA are more changeable than those of AS due to its low sensitivity in AS diagnosis and disease activity assessment [25,27]. Our results also demonstrated that $\mathrm{HbAlc}$ was not correlated with CRP $(r=0.023, p=0.842)$ and ESR $(r=0.201$, $\mathrm{p}=0.081$ ). But HbA1c was well correlated with ASDAS-CRP, which can reflect the accumulative outcome of the alteration in inflammatory burdens over time. In this regard, we first revealed that $\mathrm{HbA} 1 \mathrm{c}$ can reflect subtle impaired glucose tolerance and metabolic alterations provoked by subclinical inflammatory burdens more clearly than GA in patients with AS, unlike RA.

Although there was no statistical significance on multi- 


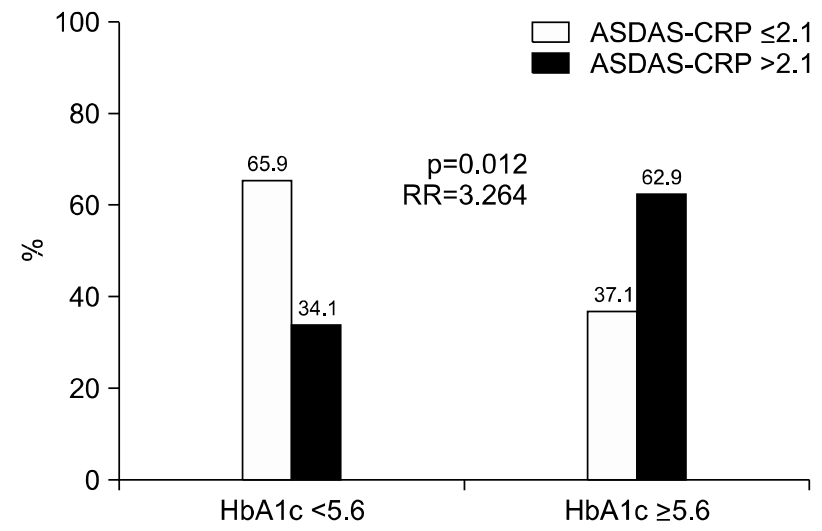

Figure 1. Optimal cut-off values of $\mathrm{HbA} 1 \mathrm{c}$ to reflect active ankylosing spondylitis. Active ankylosing spondylitis in patients having $\mathrm{HbA} 1 \mathrm{c} \geq 5.6$ was identified more often than in those having $\mathrm{HbA} 1 \mathrm{c}<5.6(62.9 \%$ vs. $34.1 \%, \mathrm{p}=0.012)$. Patients having $\mathrm{HbA} 1 \mathrm{c}$ more than 5.6 showed significantly enhanced risk of active AS than those having not $(R R=3.264)$. ASDAS: ankylosing spondylitis disease activity score, CRP: C-reactive protein, RR: relative risk, HbA1c: hemoglobin A1c, AS: ankylosing spondylitis.

variate analysis, HbAlc did show a significant difference between active and inactive AS groups based on ASDASCRP of 2.1 on univariate analysis $(\mathrm{p}=0.020)$. We assumed that this result might result from the relatively low median and mean of ASDAS-CRP as 1.8 and 2.0, which are below the cut-off of 2.1. With this reason, we set the optimal cut-off values of HbAlc to reflect active AS by calculating the area under the receiver operator characteristic curve (AUROC) and selection to maximize the sum of sensitivity (0.611) and specificity (0.675). In addition, the relative risk (RR) of the cut-off value of $\mathrm{HbAlc}$ for increased disease activity of AS was analysed using contingency tables and the chi-square test. And we found that 5.6 of HbAlc (AUROC $=0.669,95 \% \mathrm{CI}=0.547$, $0.791, \mathrm{p}=0.011$ ) was the optimal cut-off value good enough to reflect active AS. When we divided 76 patients with AS into two groups based on the calculated optimal cut-off value of $\mathrm{HbAlc}$, active AS in patients having $\mathrm{HbAlc}$ more than 5.6 was identified more often than in those having HbA1c below 5.6 (62.9\% vs. $34.1 \%, \mathrm{p}=0.012$ ). Moreover, patients having $\mathrm{HbAlc}$ more than 5.6 showed significantly enhanced risk of active AS than those having not $(\mathrm{RR}=3.264,95 \% \mathrm{CI}=1.273,8.369)$ (Figure 1). If we are able to enrol the larger number of AS patients, we could validate the statistical power of the optimal cut-off value of $\mathrm{HbAlc}$ to easily and conveniently categorise active AS or inactive AS in non-diabetic patients.

Previous studies have reported that sulfasalazine and methotrexate treatments can affect HbAlc levels $[28,29]$, so we did univariate regression analysis between these medicines use and $\mathrm{HbAlc}$, but we cannot find statistical significance (data now shown).

The strength of this study is that we first demonstrated that HbAlc was significantly correlated with ASDAS-CRP, and HbAlc could be a useful marker to reflect ASDASCRP in AS patients without medical conditions affecting glycated protein levels. Furthermore, we could set the optimal cut-off value of $\mathrm{HbAlc}$ at 5.6, and we elucidated that patients having HbAlc more than 5.6 could have enhanced risk of active AS 3.3 times as high as those having not.

We also had several issues: first, our study was a crosssectional study; second, we did not measure the parameters more directly related to HbAlc level, such as insulin resistance or intramural thickness; third, we could not perform sub-group analysis according to anti-hypertension and anti-dyslipidaemia agents, which can worsen or improve insulin resistance or beta-cell functions [30,31]. If future studies can serially measure not only $\mathrm{HbAlc}$, but also the parameters directly related to HbA1c level, they could provide a dynamic correlation between $\mathrm{HbAlc}$ and disease activity of AS. In conclusion, we herein showed that $\mathrm{HbAlc}$ was significantly correlated with ASDAS-CRP, and HbAlc could be a useful marker to reflect ASDAS-CRP in AS patients without medical conditions affecting glycated protein levels. Furthermore, we elucidated that patients having $\mathrm{HbAlc}$ more than 5.6 could have enhanced risk of active AS 3.3 times as high as those having not.

\section{CONFLICT OF INTEREST}

No potential conflict of interest relevant to this article was reported.

\section{SUPPLEMENTARY DATA}

Supplementary data can be found with this article online at https://doi.org/10.4078/jrd.2018.25.2.131.

\section{REFERENCES}

1. Pedersen SJ, Sørensen IJ, Garnero P, Johansen JS, Madsen $\mathrm{OR}$, Tvede N, et al. ASDAS, BASDAI and different treatment responses and their relation to biomarkers of inflammation, cartilage and bone turnover in patients with axial spondyloarthritis treated with $\operatorname{TNF} \alpha$ inhibitors. Ann 
Rheum Dis 2011;70:1375-81.

2. Braun J, Davis J, Dougados M, Sieper J, van der Linden S, van der Heijde D. First update of the international ASAS consensus statement for the use of anti-TNF agents in patients with ankylosing spondylitis. Ann Rheum Dis 2006;65:31620.

3. Braun J, van den Berg R, Baraliakos X, Boehm $\mathrm{H}$, Burgos-Vargas R, Collantes-Estevez E, et al. 2010 update of the ASAS/EULAR recommendations for the management of ankylosing spondylitis. Ann Rheum Dis 2011;70:896-904.

4. Dougados M, Gueguen A, Nakache JP, Velicitat P, Zeidler $\mathrm{H}$, Veys $\mathrm{E}$, et al. Clinical relevance of C-reactive protein in axial involvement of ankylosing spondylitis. J Rheumatol 1999;26:971-4.

5. Garrett S, Jenkinson T, Kennedy LG, Whitelock H, Gaisford $\mathrm{P}$, Calin A. A new approach to defining disease status in ankylosing spondylitis: the Bath Ankylosing Spondylitis Disease Activity Index. J Rheumatol 1994;21:2286-91.

6. van der Heijde D, Lie E, Kvien TK, Sieper J, Van den Bosch F, Listing J, et al. ASDAS, a highly discriminatory ASAS-endorsed disease activity score in patients with ankylosing spondylitis. Ann Rheum Dis 2009;68:1811-8.

7. Basta G, Lazzerini G, Massaro M, Simoncini T, Tanganelli P, $\mathrm{Fu} \mathrm{C}$, et al. Advanced glycation end products activate endothelium through signal-transduction receptor RAGE: a mechanism for amplification of inflammatory responses. Circulation 2002;105:816-22.

8. Goldin A, Beckman JA, Schmidt AM, Creager MA. Advanced glycation end products: sparking the development of diabetic vascular injury. Circulation 2006;114: 597-605.

9. Koga M, Kasayama S. Clinical impact of glycated albumin as another glycemic control marker. Endocr J 2010;57:751-62.

10. Koga M, Murai J, Morita S, Saito H, Kasayama S. Comparison of annual variability in $\mathrm{HbA1c}$ and glycated albumin in patients with type 1 vs. type 2 diabetes mellitus. J Diabetes Complications 2013;27:211-3.

11. Koga M, Otsuki M, Matsumoto S, Saito H, Mukai M, Kasayama S. Negative association of obesity and its related chronic inflammation with serum glycated albumin but not glycated hemoglobin levels. Clin Chim Acta 2007;378: 48-52.

12. Park JS, Song J, Park YB, Lee SK, Lee SW. Glycated albumin increases with disease activity in rheumatoid factor positive rheumatoid arthritis patients with normal fasting glucose and HbAlc. Joint Bone Spine 2017;84:115-8.

13. van der Linden S, Valkenburg HA, Cats A. Evaluation of diagnostic criteria for ankylosing spondylitis. A proposal for modification of the New York criteria. Arthritis Rheum 1984;27:361-8.

14. Koga M, Murai J, Saito H, Kasayama S, Imagawa A, Hanafusa T, et al. Serum glycated albumin to haemoglobin $\mathrm{A}(1 \mathrm{C})$ ratio can distinguish fulminant type 1 diabetes mellitus from type 2 diabetes mellitus. Ann Clin Biochem 2010;47:313-7.

15. Koga M, Murai J, Saito H, Matsumoto S, Kasayama S. Effects of thyroid hormone on serum glycated albumin levels: study on non-diabetic subjects. Diabetes Res Clin Pract 2009;84: 163-7.

16. Okada T, Nakao T, Matsumoto H, Nagaoka Y, Tomaru R, Iwasawa $\mathrm{H}$, et al. Influence of proteinuria on glycated albu- min values in diabetic patients with chronic kidney disease. Intern Med 2011;50:23-9.

17. Nomura Y, Nanjo K, Miyano M, Kikuoka H, Kuriyama S, Maeda M, et al. Hemoglobin A1 in cirrhosis of the liver. Diabetes Res 1989;11:177-80.

18. Panzer S, Kronik G, Lechner K, Bettelheim P, Neumann E, Dudczak R. Glycosylated hemoglobins (GHb): an index of red cell survival. Blood 1982;59:1348-50.

19. Machado P, Navarro-Compán V, Landewé R, van Gaalen FA, Roux C, van der Heijde D. Calculating the ankylosing spondylitis disease activity score if the conventional c-reactive protein level is below the limit of detection or if high-sensitivity c-reactive protein is used: an analysis in the DESIR cohort. Arthritis Rheumatol 2015;67:408-13.

20. Calin A, Garrett S, Whitelock H, Kennedy LG, O'Hea J, Mallorie P, et al. A new approach to defining functional ability in ankylosing spondylitis: the development of the Bath Ankylosing Spondylitis Functional Index. J Rheumatol 1994;21:2281-5.

21. Jones SD, Steiner A, Garrett SL, Calin A. The bath ankylosing spondylitis patient global score (BAS-G). Br J Rheumatol 1996;35:66-71.

22. Pu LJ, Lu L, Xu XW, Zhang RY, Zhang Q, Zhang JS, et al. Value of serum glycated albumin and high-sensitivity C-reactive protein levels in the prediction of presence of coronary artery disease in patients with type 2 diabetes. Cardiovasc Diabetol 2006;5:27.

23. Maria Z, Yin W, Rubenstein DA. Combined effects of physiologically relevant disturbed wall shear stress and glycated albumin on endothelial cell functions associated with inflammation, thrombosis and cytoskeletal dynamics. J Diabetes Investig 2014;5:372-81.

24. Gustavsson CG, Agardh CD. Markers of inflammation in patients with coronary artery disease are also associated with glycosylated haemoglobin A1c within the normal range. Eur Heart J 2004;25:2120-4.

25. Rudwaleit M, Haibel $H$, Baraliakos $X$, Listing J, Märker-Hermann E, Zeidler H, et al. The early disease stage in axial spondylarthritis: results from the German Spondyloarthritis Inception Cohort. Arthritis Rheum 2009;60: 717-27.

26. Kim KJ, Lee BW. The roles of glycated albumin as intermediate glycation index and pathogenic protein. Diabetes Metab J 2012;36:98-107.

27. Danve A, O'Dell J. The ongoing quest for biomarkers in Ankylosing Spondylitis. Int J Rheum Dis 2015;18:826-34.

28. de Rotte MC, de Jong PH, den Boer E, Pluijm SM, Özcan B, Weel AE, et al. Effect of methotrexate use and erythrocyte methotrexate polyglutamate on glycosylated hemoglobin in rheumatoid arthritis. Arthritis Rheumatol 2014;66:2026-36.

29. Krogh Jensen M, Ekelund S, Svendsen L. Folate and homocysteine status and haemolysis in patients treated with sulphasalazine for arthritis. Scand J Clin Lab Invest 1996; 56:421-9.

30. Lithell HO. Effect of antihypertensive drugs on insulin, glucose, and lipid metabolism. Diabetes Care 1991;14:203-9.

31. Goyal A, Singh S, Tandon N, Gupta N, Gupta YK. Effect of atorvastatin on pancreatic Beta-cell function and insulin resistance in type 2 diabetes mellitus patients: a randomized pilot study. Can J Diabetes 2014;38:466-72. 
pISSN: 2093-940X, elSSN: 2233-4718

Journal of Rheumatic Diseases Vol. 25, No. 2, April, 2018

https://doi.org/10.4078/jrd.2018.25.2.131

Supplementary Table 1. Correlation among variables related to glucose metabolism and disease activity of ankylosing spondylitis $(n=76)$

\begin{tabular}{|c|c|c|c|c|c|c|c|c|}
\hline & $\mathrm{BMI}$ & $\mathrm{HbA1c}$ & GA & Fasting glucose & ASDAS-ESR & ASDAS-CRP & BASDAI & BAS-G \\
\hline BMI & 1 & & & & & & & \\
\hline $\mathrm{HbA} 1 \mathrm{c}$ & $0.227^{*}$ & 1 & & & & & & \\
\hline GA & $-0.268^{*}$ & $0.400 *$ & 1 & & & & & \\
\hline Fasting glucose & $0.331 *$ & $0.405^{*}$ & 0.186 & 1 & & & & \\
\hline ASDAS-ESR & 0.013 & 0.220 & 0.105 & 0.011 & 1 & & & \\
\hline ASDAS-CRP & 0.032 & $0.315^{*}$ & 0.135 & 0.037 & $0.792 *$ & 1 & & \\
\hline BASDAI & 0.019 & $0.226^{*}$ & 0.192 & 0.010 & $0.719^{*}$ & $0.774^{*}$ & 1 & \\
\hline BAS-G & 0.039 & $0.401 *$ & 0.221 & 0.166 & $0.568^{*}$ & $0.617^{*}$ & $0.655^{*}$ & 1 \\
\hline BASFI & -0.118 & 0.124 & 0.111 & 0.013 & $0.376^{*}$ & $0.322 *$ & 0.211 & $0.279 *$ \\
\hline
\end{tabular}

BMI: body mass index, HbA1c: haemoglobin A1c, GA: glycated albumin, ASDAS: ankylosing spondylitis disease activity score, BASDAI: Bath ankylosing spondylitis disease activity index, BAS-G: Bath ankylosing spondylitis patient global score, BASFI: Bath ankylosing spondylitis disease activity functional index. ${ }^{*} \mathrm{p}<0.05$. 